\title{
Analyzing Attitude towards COVID-19 Vaccine in the Context of the Health Industry: The Role of Country of Origin Image
}

\author{
COVID-19 Aşısına Yönelik Tutumların Sağlık Sektörü Açısından Analizi: Menşei Ülke İmajının \\ Rolü
}

\author{
Kenan AYDIN \\ (1) 0000-0002-0496-5665 \\ Ece ÖZER ÇIZZER \\ (D) 0000-0002-8597-2073 \\ Şirin Gizem KÖSE \\ (i) 0000-0003-4075-7166
}

\begin{abstract}
Aim: The aim of this study is to investigate individuals' attitude towards the coronavirus disease 2019 (COVID-19) vaccine, and explain vaccination intention in the framework of the theory of reasoned action. The study extends the theory of reasoned action with country of origin image variable.

Material and Methods: The data of the study were collected by survey method. The survey consists of a total of 48 items, including individual innovativeness, subjective norms, attitude towards COVID-19 vaccine, intention to get COVID-19 vaccine, country of origin image, demographic characteristics, and general opinions about the vaccine and COVID-19. 333 participants answered the surveys. Data were analyzed by structural equation modeling using SPSS v. 21 and AMOS v.23 package programs.

Results: Attitude towards German COVID-19 vaccine $(\beta=0.888, \mathrm{p}<0.001)$ and German's country of origin $(\beta=0.436, p<0.001)$ variables have significant and positive relationships with intention to get German vaccine. Subjective norms $(\beta=0.750, p<0.001)$, China's country of image $(\beta=0.265, p<0.001)$, attitude towards Chinese COVID-19 vaccine $(\beta=0.198, p<0.001)$, vaccine. Country of origin image is significantly and positively related to both attitude towards German COVID-19 vaccine $(\beta=0.690, p<0.001)$ and Chinese COVID-19 vaccine $(\beta=0.461$, $\mathrm{p}<0.001)$.

Conclusion: The most important factor associated with the intention to get German COVID19 vaccine is the attitude towards the COVID-19 vaccine. The most important factor associated with the intention to get Chinese COVID-19 vaccine is the subjective norm. Country of origin image is a significant variable for both countries.

Keywords: COVID-19 vaccine; theory of reasoned action; country of origin image; public health.
\end{abstract}

Yildız Technical University Faculty of variables have significant and positive relationships with intention to get Chinese COVID-19 Economics and Administrative Sciences Department of Business Administration, İstanbul, Turkey

\section{Corresponding Author Sorumlu Yazar Ece ÖZER ÇİZER ece.ozer@icloud.com}

Received / Geliş Tarihi : 15.01.2021 Accepted / Kabul Tarihi : 24.03.2021 Available Online /

Çevrimiçi Yayın Tarihi : 25.03.2021
ÖZ

Amaç: Bu çalışmanın amacı, bireylerin koronavirüs hastalığı 2019 (coronavirus disease 2019, COVID-19) aşısına yönelik tutumlarını inceleyerek, aşı olma niyetini gerekçeli eylem teorisi çerçevesinde açıklamaktır. Çalışma gerekçeli eylem teorisini menşei ülke imajı değişkeni ile genişletmektedir.

Gereç ve Yöntemler: Çalışmanın verileri anket yöntemiyle toplanmıştır. Anket, bireysel yenilikçilik, subjektif normlar, COVID-19 aşısına yönelik tutum, COVID-19 aşısı olma niyeti, menşe ülke imajı, demografik özellikler ve aşı ve COVID-19 hakkında genel görüşler dahil olmak üzere toplam 48 maddeden oluşmaktadır. 333 katılımcı anketleri cevaplandırmıştır. Veriler SPSS v. 21 ve AMOS v.23 paket programları kullanılarak yapısal eşitlik modellemesi ile analiz edilmiştir.

Bulgular: Alman COVID-19 aşısına yönelik tutum $(\beta=0,888 ; p<0,001)$ ve Almanya'nın menşei ülke imajı $(\beta=0,436 ; p<0,001)$ değişkenleri, Alman aşısı olma niyeti ile anlamlı ve pozitif ilişkilidir. Subjektif normlar $(\beta=0,750 ; p<0,001)$, Çin'in menşei ülke imajı $(\beta=0,265$; $\mathrm{p}<0,001)$, ve Çin aşısına yönelik tutum $(\beta=0,198 ; \mathrm{p}<0,001)$ değişkenleri Çin aşısı olma niyeti ile anlamlı ve pozitif ilişkilidir. Menşei ülke imajı, hem Alman COVID-19 aşısına yönelik tutum ile $(\beta=0,690 ; p<0,001)$, hem de Çin COVID-19 aşısına yönelik tutum $(\beta=0,461$; $\mathrm{p}<0,001)$ ile anlamlı ve pozitif ilişkilidir.

Sonuç: Alman COVID-19 aşısı olma niyeti ile ilişkili en önemli faktör Alman COVID-19 aşısına yönelik tutumdur. Çin COVID-19 aşısı olma niyetiyle ilişkili en önemli faktör, subjektif normlardır. Menşei ülke imajı, her iki ülke için de önemli bir değişkendir.

Anahtar kelimeler: COVID-19 aşısı; gerekçeli eylem teorisi; menşei ülke imajı; halk sağlı̆̆ı. 


\section{INTRODUCTION}

Coronavirus disease 2019 (COVID-19) emerged in China in 2019 and has been called a pandemic by World Health Organization (WHO). The COVID-19 pandemic changed human life, ways of working, and almost all systems. The health industry made a great effort during the pandemic and it is one of the most affected industries from the virus. The health industry quickly adapted itself to pandemic conditions and also continuously worked on vaccine development. Even though vaccine development is a long process, considerable progress was made.

Although the importance of vaccination to prevent diseases is known, there is still hesitation to get vaccines in societies. Vaccine hesitancy is one of the most discussed concepts in health science and there are also debates on this issue in public. Vaccine hesitancy is defined as the behavior with delay in acceptance or refusal of vaccines despite available services. The hesitancy depolarized the vaccine supporters and anti-vaccine counterparts (1). According to Palm et al.'s (2) study people who were informed on the safety/effectiveness of the vaccine were more likely to report that they would take the vaccine; the finding highlights the importance of informing people about the vaccine. Furthermore, when people were informed about political influences on vaccine development, they were hesitant to get the vaccine. Salali and Uysal's (3) study shows that $31 \%$ of the participants were hesitant to get the vaccine while $3 \%$ reject to get the vaccine. The success of the vaccine campaigns to control COVID-19 does not only depend on the effectiveness and/or safety of the vaccine but also the acceptance of the public. Another study in America demonstrates that the rate of rejection is $30 \%$ even for a vaccine that has optimal qualities (4). Sallam's (5) study points out that the vaccine acceptance rate is low in Middle East, Russia, Africa, and several European countries. In this direction, it is seen that more studies on vaccination intention are needed in those countries.

To fill this void, this study aims to explain factors related to intention to get COVID-19 vaccine in the framework of the theory of reasoned action since the first step to understand vaccination intention is determining the factors associated with the intention. This study also intends to investigate the effect of country of origin image on this decision with a multidisciplinary perspective. Furthermore, this study presents participants' attitudes towards the COVID-19 vaccine, their opinions on the COVID-19 virus and COVID-19 vaccine. Together with these, the moderator role of individual innovativeness in the relationship between country of origin image and COVID-19 vaccination intention is examined.

\section{MATERIAL AND METHODS}

\section{Theory of Reasoned Action}

One of the fundamental theories that explain consumers' product/service adaptation decision is the theory of reasoned action (6). This theory is utilized as a common model to predict behavior and/or behavioral intention (7).

Theory of reasoned action states that attitude, subjective norm, and behavioral intention variables affect behavior. According to the theory, individuals' behavioral intention is explained by attitude and subjective norm (8). In this respect; attitude is "affective or valenced response toward performing some behavior", and subjective norm is "a person's belief about whether significant others feel that he or she should perform the target behavior" (9).

This study used attitude and subjective norms as antecedents of behavioral intention in the framework of the theory of reasoned action and extended the theory with country of origin image variable.

\section{Country of Origin Image}

Countries give cues to help consumers evaluate the products (10). The country where the headquarters are located is conceptualized as country of origin in the marketing literature (11). One of the fundamental constructs of country of origin is country of origin image (12). Country of origin image is the foundation of country reputation, attractiveness, and brand image. Positive country or origin image contributes to the economic, social, and political power of the country (13). Country of origin image is conceptualized as the attitude towards a country (14). One of the first definitions of country of origin image belongs to Nagashima (15) who defines country of origin image as "the image that consumers associate or attach to products of a specific country".

Consumers use their beliefs or perceptions about a country to evaluate the country's brands $(16,17)$. The researches in the literature show that country of origin image affects product image and product judgments (18), brand image and brand evaluation (19), consumers' attitudes (20), and purchase intention (19-23).

The research on generic drugs shows that country of origin image affects brand power and brand awareness, which are the components of brand equity in this category (24). Similarly, study by Smaoui et al. (25) concludes that country of origin affects consumers' perception of drug quality and trust. Another research on over-the-counter medicines states that country of origin is a determinant of purchase intention (26).

Although country of origin image variable was tested on several product groups, there is a need to conduct research on the vaccine. Country of origin of the vaccine comes to the forefront as an important factor in predicting vaccination intention.

\section{Individual Innovativeness}

When new technologies and products are introduced to the market, consumers reach them differently. It is expected that people who have a high level of individual innovativeness adapt to innovation more quickly (27) and earlier than others (28). The level of individual innovativeness affects individuals' reactions to the vaccine, especially when there is uncertainty. Also, vaccines are directly related to a person's health so the risk is also higher. Goldsmith's (29) findings show that consumer innovativeness theories can be extended to different consumption areas. Accordingly, innovative consumers tend to be consistent regardless of the product category. Innovativeness as a personality trait was used as a moderator variable in studies in the literature (30-32). Therefore, the innovativeness level of individuals is included as a moderator variable in the research.

In the light of the theoretical framework, the following research models are formed. Figure 1 and Figure 2 show the research models of the study. 


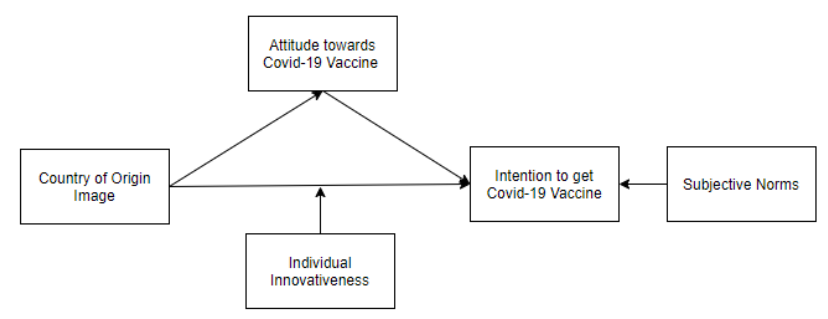

Figure 1. Research model (Germany)

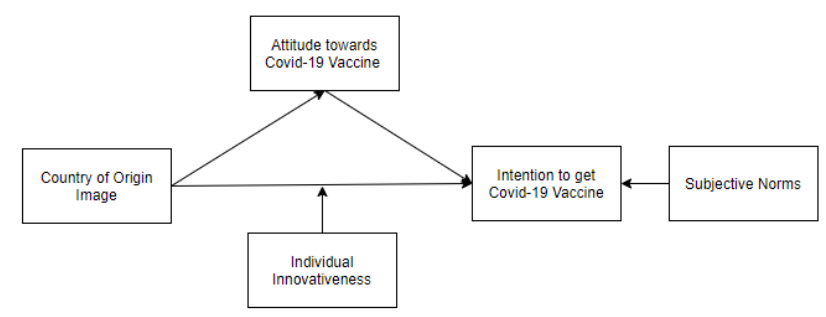

Figure 2. Research model (China)

H1: There is a positive relationship between Germany's country of origin image and intention to get German vaccine.

$\mathrm{H} 2$ : There is a positive relationship between Germany's country of origin image and attitude towards German vaccine.

H3: Attitude towards German vaccine mediates the relationship between Germany's country of origin and intention to get German vaccine.

H4: Individual innovativeness moderates the relationship between Germany's country of origin image and intention to get German vaccine.

H5: There is a positive relationship between attitude towards German vaccine and intention to get German vaccine.

H6: There is a positive relationship between subjective norms and intention to get German vaccine.

H7: There is a positive relationship between China's country of origin image and intention to get Chinese vaccine.

H8: There is a positive relationship between China's country of origin image and attitude towards Chinese vaccine.

H9: Attitude towards Chinese vaccine mediates the relationship between China's country of origin and intention to get Chinese vaccine.

H10: Individual innovativeness moderates the relationship between China's country of origin image and intention to get Chinese vaccine.

H11: There is a positive relationship between attitude towards Chinese vaccine and intention to get Chinese vaccine.

H12: There is a positive relationship between subjective norms and intention to get Chinese vaccine.

\section{Survey Design}

In the survey form used in the study, preliminary information was given to the participants about the scope of the study, that the participant information would be kept confidential and about the researchers. Later, 48 scale items were included to test the hypotheses of the research, the items were prepared as a 5-point Likert scale.
Individual innovativeness with four items adapted from Flynn and Goldsmith (33), subjective norms with three items adapted from Nysveen et al. (34), attitude towards COVID-19 vaccine with three items adapted from Hamari et al. (35), intention to get COVID-19 vaccine with three items adapted from Sherman et al. (36) and country of origin image is measured by seven items adapted from Hien (19).

In the last part of the survey, there are questions about demographic characteristics and questions to measure general opinions about the vaccine and COVID-19.

\section{Data Collection}

The data of the study were collected using the survey method with convenience sampling. The research population is Turkish citizens who have knowledge about the COVID-19 vaccine. A total of 334 surveys were collected from the participants living in İstanbul. A survey was not included in the analysis because it has extreme values. The study was approved by the Social and Humanities Research Ethics Committee of Y1ldiz Technical University (2021/01).

\section{Statistical Analysis}

SPSS v.21 and AMOS v.23 programs were used to test the research model and hypotheses. Analysis results are included under the headings of demographic characteristics, reliability, validity and exploratory factor analysis findings, structural equation modeling and hypothesis tests.

\section{RESULTS \\ Demographic Characteristics of the Participants}

Table 1 demonstrates the demographic information about the participants. According to Table 1, 61\% of the participants are female and $39 \%$ are male participants. Majority of the participants $(59.5 \%)$ have bachelor degree. Participants aged between 18 and 29 constituted $55.3 \%$ of the total participants. Finally, information on household income level and occupation were obtained from the participants. $28 \%$ of the participants' household income level is $10,000 \mathrm{TL}$ and above while $26.4 \%$ or the participants' is between 2.501 and 5.000 TL. $37.5 \%$ of the participants works at private sector while $32.4 \%$ of the participants are students.

Reliability, Validity and Exploratory Analysis Results In order to determine the factor structures of the variables in the study, exploratory factor analysis was applied first. In the exploratory factor analysis, two important parameters were taken into consideration: KMO test and Bartlett sphericity test. According to Sharma (37), KMO test should be above 0.60 and Bartlett sphericity test should be less than 0.05 for sampling adequacy in measuring the suitability of the data collected by the survey method to factor analysis. As given in Table 2, KMO values for the scales are in the range of 0.722-0.919. Accordingly, it is understood that the sample size is suitable for factor analysis. Bartlett sphericity test results were also significant $(\mathrm{p}<0.05)$. Accordingly, it is understood that the correlation between the items of the scales is adequate for factor analysis (38).

According to Hair et al. (39), the internal reliability, convergent and discriminant validity of the scales used in the structural model should be tested at the first stage. In order for the scales to be accepted as internally reliable, the 
Cronbach alpha value and the composite validity value should be 0.70 and above (40). When the values related to the scales are examined in Table 2, it has been determined that the Cronbach alpha values are in the range of 0.823 0.969 and have a very high reliability. CR (composite reliability) values are in the range of $0.785-0.967$, AVE values are above the limit value determined as 0.70 and meet the combination validity requirements. Accordingly, the scales have a high degree of reliability and combination validity and are internally reliable. AVE values and factor loadings should be 0.50 and above in order to accept convergent validity. In order to ensure discriminant validity, the square roots of the AVE values should be greater than the correlation values between the structures $(41,42)$. According to Table 2, factor loadings and AVE values are above the limit value of 0.5 , ensuring convergent validity. In Table 3 and Table 4, the inter-structure correlations and the square roots of the AVE values are given. The square roots of the AVE values are shown diagonally. Correlations between structures were lower than the square roots of AVE values. Accordingly, discriminant validity is provided. In addition, the table includes skewness and kurtosis values. Limit values for skewness and kurtosis are determined as -1.5 and +1.5 intervals. Accordingly, the data set has a normal distribution (43). In the research, the criteria of goodness of fit were examined by applying confirmatory factor analysis with the AMOS program. Confirmatory factor analysis goodness of fit values for the Germany model were found as "CFI: 0.965, CMIN/df: 2.514, SRMR: 0.053, GFI: 0.894, AGFI: 0.857, RMSEA: 0.068", while for China it was "CFI: 0.964, CMIN/df: 2.160, SRMR: 0.052, GFI: 0.902, AGFI: 0.870, RMSEA: 0.059". Both models have values above the limit values (44).

Table 1. Demographic characteristics, $n=333$

\begin{tabular}{lcc}
\hline Demographic Characteristics & $\mathbf{n}$ & $\mathbf{\%}$ \\
\hline Gender & & \\
$\quad$ Female & 203 & 61.0 \\
$\quad$ Male & 130 & 39.0 \\
Education Level & & \\
$\quad$ High School and below & 31 & 9.3 \\
$\quad$ Bachelor Degree & 198 & 59.5 \\
Master's Degree & 96 & 28.8 \\
Doctorate Degree & 8 & 2.4 \\
Age & & \\
18 - 29 & 184 & 55.3 \\
30 - 39 & 61 & 18.3 \\
40 - 49 & 38 & 11.4 \\
50 - 64 & 46 & 13.8 \\
65 and above & 4 & 1.2 \\
Household Income & & \\
2,500 TL and below & 17 & 5.1 \\
2,501 - 5,000 TL & 88 & 26.4 \\
5,001 -7,500 TL & 67 & 20.1 \\
7,501 - 10,000 TL & 65 & 19.5 \\
10,001 TL and above & 96 & 28.8 \\
Occupation & & \\
Public Employee & 61 & 18.3 \\
Private Sector Employee & 125 & 37.5 \\
Entrepreneur & 9 & 2.7 \\
Student & 108 & 32.4 \\
Retired & 16 & 4.8 \\
Unemployed & 14 & 4.2 \\
\hline
\end{tabular}

\section{Structural Equation Modeling and Hypothesis Tests}

The hypotheses of the research were tested with path analysis by establishing structural equation modeling. Two different models have been established for Germany and China. The goodness of fit values of the established models were examined, and the fit values for model 1 (without mediator variable) and model 2 (with mediator variable) were given in Table 5 and Table 8 . According to the model goodness of fit values determined by Hair (40), it is seen that the fit values of the research models are above the limits.

Table 2. Exploratory factor analysis, reliability and validity results

\begin{tabular}{|c|c|c|c|c|}
\hline Items & Factor Loadings & Cronbach $\alpha$ & CR & AVE \\
\hline \multicolumn{5}{|c|}{$\begin{array}{l}\text { Subjective norms } \\
\text { (KMO: } 0.763 \text {, Bartlett's: } 802.498, \text { df: } 3, p<0.001)\end{array}$} \\
\hline$\overline{\mathrm{S} 1}$ & 0.935 & \multirow{3}{*}{0.93} & \multirow{3}{*}{0.93} & \multirow{3}{*}{0.8} \\
\hline $\mathrm{S} 2$ & 0.929 & & & \\
\hline $\mathrm{S} 3$ & 0.946 & & & \\
\hline \multicolumn{5}{|c|}{$\begin{array}{l}\text { Germany's country of origin image } \\
\text { (KMO: } 0.919, \text { Bartlett's: } 3043.530, \text { df: } 21, p<0.001 \text { ) }\end{array}$} \\
\hline GCOI1 & 0.904 & \multirow{7}{*}{0.97} & \multirow{7}{*}{0.97} & \multirow{7}{*}{0.8} \\
\hline GCOI2 & 0.924 & & & \\
\hline GCOI3 & 0.911 & & & \\
\hline GCOI4 & 0.940 & & & \\
\hline GCOI5 & 0.906 & & & \\
\hline GCOI6 & 0.923 & & & \\
\hline GCOI7 & 0.916 & & & \\
\hline \multicolumn{5}{|c|}{$\begin{array}{l}\text { Attitude towards German COVID-19 Vaccine } \\
\text { (KMO:0.727, Bartlett's: } 1129.224 \text {, df: } 3, \mathrm{p}<0.001)\end{array}$} \\
\hline$\overline{\text { AG1 }}$ & 0.966 & \multirow{3}{*}{0.95} & \multirow{3}{*}{0.95} & \multirow{3}{*}{0.9} \\
\hline AG2 & 0.971 & & & \\
\hline AG3 & 0.917 & & & \\
\hline \multicolumn{5}{|c|}{$\begin{array}{l}\text { Intention to get German COVID-19 Vaccine } \\
\text { (KMO:0.763, Bartlett's: } 806.241 \text {, df: } 3, p<0.001 \text { ) }\end{array}$} \\
\hline$\overline{\text { IG1 }}$ & 0.930 & \multirow{3}{*}{0.93} & \multirow{3}{*}{0.93} & \multirow{3}{*}{0.8} \\
\hline IG2 & 0.946 & & & \\
\hline IG3 & 0.935 & & & \\
\hline \multicolumn{5}{|c|}{$\begin{array}{l}\text { China's country of origin image } \\
\text { (KMO: } 0.902 \text {, Bartlett's: } 1663.293 \text {, df: } 21, \mathrm{p}<0.001)\end{array}$} \\
\hline$\overline{\mathrm{CCOI}}$ & 0.807 & \multirow{7}{*}{0.93} & \multirow{7}{*}{0.92} & \multirow{7}{*}{0.6} \\
\hline $\mathrm{CCOI} 2$ & 0.852 & & & \\
\hline $\mathrm{CCOI} 3$ & 0.852 & & & \\
\hline CCOI4 & 0.879 & & & \\
\hline CCOI5 & 0.769 & & & \\
\hline CCOI6 & 0.821 & & & \\
\hline $\mathrm{CCOI} 7$ & 0.843 & & & \\
\hline \multicolumn{5}{|c|}{$\begin{array}{l}\text { Attitude towards Chinese COVID-19 Vaccine } \\
\text { (KMO: } 0.722 \text {, Bartlett's: } 671.727 \text {, df: } 3, p<0.001)\end{array}$} \\
\hline$\overline{\mathrm{AC} 1}$ & 0.933 & \multirow{3}{*}{0.90} & \multirow{3}{*}{0.90} & \multirow{3}{*}{0.8} \\
\hline $\mathrm{AC} 2$ & 0.935 & & & \\
\hline AC3 & 0.870 & & & \\
\hline \multicolumn{5}{|c|}{$\begin{array}{l}\text { Intention to get Chinese COVID-19 Vaccine } \\
\text { (KMO: } 0.766 \text {, Bartlett's: } 1143.100, \text { df: } 3, \mathrm{p}<0.001)\end{array}$} \\
\hline IC1 & 0.958 & & & \\
\hline IC2 & 0.973 & 0.96 & 0.96 & 0.9 \\
\hline IC3 & 0.956 & & & \\
\hline $\begin{array}{l}\text { Individual } \\
\text { (KMO: } 0.7\end{array}$ & $\begin{array}{l}\text { novativeness } \\
\text { Bartlett's: } 770.910 \text {, }\end{array}$ & df: $10, p<0.0$ & & \\
\hline II1 & 0.757 & & & \\
\hline II 2 & 0.824 & & & \\
\hline II3 & 0.612 & 0.82 & 0.78 & 0.5 \\
\hline II4 & 0.811 & & & \\
\hline II5 & 0.813 & & & \\
\hline
\end{tabular}


Table 3. Descriptive statistics and correlations (Germany)

\begin{tabular}{lccccccccc}
\hline Factor & Mean & SD & Skew. & Kurt. & $\mathbf{1}$ & $\mathbf{2}$ & $\mathbf{3}$ & $\mathbf{4}$ & $\mathbf{5}$ \\
\hline Country of origin & 3.764 & 1.054 & -1.183 & 0.940 & $\mathbf{0 . 8 9 8}$ & & & & \\
Attitude & 3.278 & 1.121 & -0.417 & -0.447 & 0.677 & $\mathbf{0 . 9 3 0}$ & & \\
Intention & 3.129 & 1.079 & -0.273 & -0.496 & 0.548 & 0.768 & $\mathbf{0 . 9 0 4}$ & \\
Subjective norms & 3.199 & 1.135 & -0.422 & -0.729 & 0.547 & 0.631 & 0.444 & $\mathbf{0 . 9 0 3}$ & \\
Individual innovativeness & 2.508 & 0.829 & 0.191 & -0.471 & 0.383 & 0.235 & 0.348 & 0.231 & $\mathbf{0 . 6 7 5}$ \\
\hline
\end{tabular}

Table 4. Descriptive statistics and correlations (China)

\begin{tabular}{lccccccccc}
\hline Factor & Mean & SD & Skew. & Kurt. & $\mathbf{1}$ & $\mathbf{2}$ & $\mathbf{3}$ & $\mathbf{4}$ & $\mathbf{5}$ \\
\hline Country of origin & 3.109 & 0.967 & -0.402 & -0.294 & 0.796 & & & & \\
Attitude & 2.644 & 0.886 & -0.264 & -0.315 & 0.461 & 0.868 & & \\
Intention & 2.662 & 1.065 & 0.096 & -0.606 & 0.433 & 0.810 & 0.944 & \\
Subjective norms & 3.199 & 1.135 & -0.422 & -0.729 & 0.453 & 0.397 & 0.477 & 0.904 & \\
Individual innovativeness & 2.508 & 0.829 & 0.191 & -0.471 & 0.211 & 0.163 & 0.149 & 0.230 & 0.675 \\
\hline
\end{tabular}

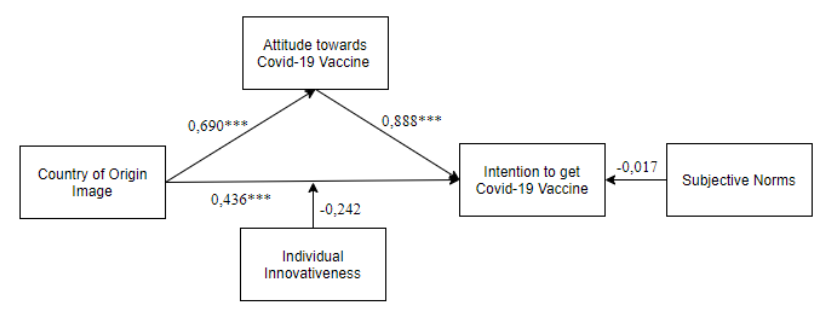

Figure 3. Path analysis results (Germany). ***: $\mathrm{p}<0.001$

The model of the study established for Germany is given in Figure 3. Path coefficients and significance levels are shown on the model. According to Table 5, which includes the hypothesis test results for the German model; there is a positive and significant relationship between Germany's country of origin image and the intention to get a German vaccine $(\beta=0.436, \mathrm{p}<0.001)$ and attitude towards getting a German vaccine $(\beta=0.690, p<0.001)$. Hence, the $\mathrm{H} 1$ and $\mathrm{H} 2$ hypotheses were supported. A significant and positive relationship $(\beta=0.888, p<0.001)$ was found between attitude towards German COVID-19 vaccine and intention to get German COVID-19 vaccine, and H5 was supported. There was no significant and positive correlation $(\beta=-$ $0.017, \mathrm{p}=0.708$ ) between subjective norms and intention to get a German vaccine. Hence, the H6 hypothesis was not supported.

Two separate models were created to test the role of attitude towards German COVID-19 vaccine mediator (Table 6). Model 1 does not contain mediator variables. Model 2 contains the mediator variable. Then, the significance values and path coefficients of these models were compared. In Model 1, the path between Germany's country of origin image and intention to get German COVID-19 vaccine is positive and significant $(\beta=0.436$, $\mathrm{p}<0.001)$. Adding the attitude in model 2 distorted the significance value $(\beta=-0.066, p=0.271)$. The deterioration in significance value and path coefficient proves the mediating role in the relationship between attitude towards German COVID-19 vaccine, Germany's country of origin image and intention to get German COVID-19 vaccine.

Table 5. Hypothesis testing results (Germany)

\begin{tabular}{|c|c|c|c|c|c|c|c|}
\hline \multirow{2}{*}{$\begin{array}{c}\text { Hypothesis } \\
\text { H1 (Model 1) }\end{array}$} & \multicolumn{2}{|c|}{ Path } & \multirow{2}{*}{$\frac{\text { Std. } \beta}{0.436}$} & \multirow{2}{*}{$\begin{array}{c}\text { Std. Error } \\
0.442\end{array}$} & \multirow{2}{*}{$\begin{array}{c}\text { C.R. } \\
0.062\end{array}$} & \multirow{2}{*}{$\frac{\mathbf{p}}{* * *}$} & \multirow{2}{*}{$\frac{\text { Result }}{\text { Supported }}$} \\
\hline & G.COI & G.Int. & & & & & \\
\hline H2 (Model 2) & G.COI & G.Att. & 0.690 & 0.050 & 13.838 & $* * *$ & Supported \\
\hline H5 (Model 2) & G.Att. & G.Int. & 0.888 & 0.067 & 13.279 & $* * *$ & Supported \\
\hline H6 (Model 2) & S.Norms & G.Int. & -0.017 & 0.044 & -0.374 & 0.708 & Not Supported \\
\hline
\end{tabular}

Model Fit Indices

Model 1: CFI: 0.974, CMIN/df: 3.089, SRMR: 0.033, GFI: 0.921, AGFI: 0.882, RMSEA: 0.079

Model 2: CFI: 0.970, CMIN/df: 3.143, SRMR: 0.073, GFI: 0.910, AGFI: 0.869, RMSEA: 0.080

Table 6. Mediation analysis results (Germany)

\begin{tabular}{rcccccccc}
\hline & Hypothesis & \multicolumn{2}{c}{ Path } & Std. $\boldsymbol{\beta}$ & Std. Error & C.R. & p & Result \\
\hline \multirow{2}{*}{ H3 } & (Model 1) & G.COI & G.Int. & 0.436 & 0.442 & 0.062 & $* * *$ & \multirow{2}{*}{ Supported } \\
& (Model 2) & G.COI & G.Int. & -0.066 & 0.061 & -1.1 & 0.271 & \\
\hline
\end{tabular}


It aimed to examine moderator role of individual innovations in the relationship between China's country of origin image and intention to get German COVID-19 vaccine. For this, individual innovations' moderator role tested using the AMOS program. The interaction term was created by multiplying the averages of Germany's country of origin image and individual innovations, and it was tested path between the interaction term and intention to get German COVID-19 vaccine. According to Table 7, which includes the analysis results, individual innovations is not a moderator $(\beta=-0.242, p=0.314)$ in the relationship between Germany's country of origin image and intention to get German COVID-19 vaccine.

The model of the study established for China is given in Figure 4. Path coefficients and significance levels are shown on the model. According to Table 8, which includes the hypothesis test results for the Chinese model; there is a positive and significant relationship between China's country of origin image and the intention to get a Chinese vaccine $(\beta=0.265, p<0.001)$ and the attitude towards Chinese vaccine $(\beta=0.461, \mathrm{p}<0.001)$, so the $\mathrm{H} 7$ and $\mathrm{H} 8$

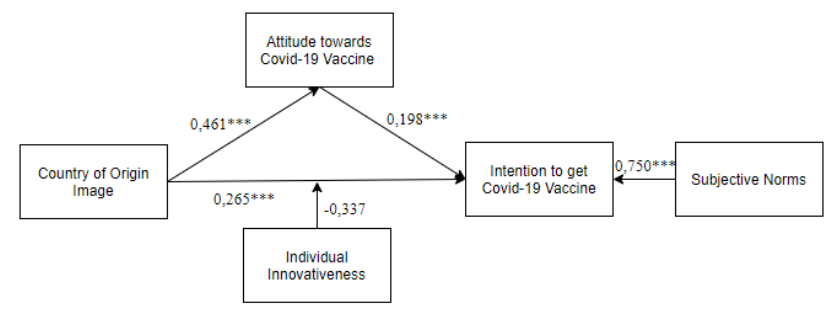

Figure 4. Path analysis results (China). ***: $p<0.001$ hypotheses were supported. A significant and positive relationship was found between attitudes towards Chinese vaccine and intention to get Chinese COVID-19 vaccine $(\beta=0.198, \quad p<0.001)$ and subjective norms $(\beta=0.750$, $\mathrm{p}<0.001$ ), and $\mathrm{H} 11$ and $\mathrm{H} 12$ were supported.

Two separate models were created to test the role of attitude towards Chinese COVID-19 vaccine mediator (Table 9). Model 1 does not contain mediator variables. Model 2 contains the mediator variable. Then, the significance values and path coefficients of these models were compared. In Model 1, the path between China's country of origin image and intention to get Chinese COVID-19 vaccine is positive and significant $(\beta=0.265$, $\mathrm{p}<0.001)$. Adding the attitude in Model 2 distorted the significance value $(\beta=-0.006, p=0.900)$. The deterioration in significance value and path coefficient proves the mediating role in the relationship between attitude towards Chinese COVID-19 vaccine, China's country of origin image and intention to get Chinese COVID-19 vaccine.

It aimed to examine moderator role of individual innovations in the relationship between China's country of origin image and intention to get Chinese COVID-19 vaccine. For this, individual innovations' moderator role tested using the AMOS program. The interaction term was created by multiplying the averages of China's country of origin image and individual innovations, and it was tested path between the interaction term and intention to get Chinese COVID-19 vaccine. According to Table 10, individual innovations' moderator role $(\beta=-0.337$, $\mathrm{p}=0.129)$ does not exist in the relationship between China's country of origin image and intention to get Chinese COVID-19 vaccine.

Table 7. Moderation analysis results (Germany)

\begin{tabular}{|c|c|c|c|c|c|c|c|}
\hline Hypothesis & & & Std. $\beta$ & Std. Error & C.R. & p & Result \\
\hline H4 & G.COI*II & G.Int. & -0.242 & 0058 & -1.006 & 0.314 & Not Sunnorted \\
\hline
\end{tabular}

G.COI*II: Individual innovativeness (interaction term)

Table 8. Hypothesis testing results (China)

\begin{tabular}{|c|c|c|c|c|c|c|c|}
\hline \multirow{2}{*}{$\begin{array}{c}\text { Hypothesis } \\
\text { H7 (Model 1) }\end{array}$} & \multicolumn{2}{|c|}{ Path } & \multirow{2}{*}{$\frac{\text { Std. } \beta}{0.265}$} & \multirow{2}{*}{$\begin{array}{c}\text { Std. Error } \\
0.064\end{array}$} & \multirow{2}{*}{$\begin{array}{c}\text { C.R. } \\
4.556\end{array}$} & \multirow{2}{*}{$\frac{\mathbf{p}}{* * *}$} & \multirow{2}{*}{$\begin{array}{c}\text { Result } \\
\text { Supported }\end{array}$} \\
\hline & C.COI & C.Int. & & & & & \\
\hline H8 (Model 2) & C.COI & C.Att. & 0.461 & 0.056 & 7.980 & $* * *$ & Supported \\
\hline H11 (Model 2) & C.Att. & C.Int. & 0.198 & 0.039 & 4.734 & $* * *$ & Supported \\
\hline H12 (Model 2) & S.Norms & C.Int. & 0.750 & 0.053 & 15.605 & $* * *$ & Supported \\
\hline
\end{tabular}

Model Fit Indices

Model 1: CFI: 0.975, CMIN/df: 2.068, SRMR: 0.039, GFI: 0.934, AGFI: 0.899, RMSEA: 0.070

Model 2: CFI: 0.973, CMIN/df: 2.334, SRMR: 0.058, GFI: 0.922, AGFI: 0.891, RMSEA: 0.063

Table 9. Mediation analysis results (China)

\begin{tabular}{lcccccccc}
\hline & Hypothesis & \multicolumn{2}{c}{ Path } & Std. $\boldsymbol{\beta}$ & Std. Error & C.R. & p & Result \\
\hline \multirow{2}{*}{ H9 } & (Model 1) & C.COI & C.Int. & 0.265 & 0.064 & 4.556 & $* * *$ & \multirow{2}{*}{ Supported } \\
& (Model 2) & C.COI & C.Int. & 0.006 & 0.050 & 0.126 & 0.900 & \\
\hline
\end{tabular}

Table 10. Moderation analysis results (China)

\begin{tabular}{cccccccc}
\hline Hypothesis & \multicolumn{2}{c}{ Path } & Std. $\boldsymbol{\beta}$ & Std. Error & C.R. & p & Result \\
\hline H10 & C.COI*II & C.Int. & -0.337 & 0.062 & -1.518 & 0.129 & Not Supported \\
\hline
\end{tabular}

C.COI*II: Individual innovativeness (interaction term) 


\section{DISCUSSION}

While the COVID-19 pandemic affects the whole world, vaccination studies are also increasing. Turkey has also started vaccination. This study aims to investigate the antecedents of vaccination intention in the framework of theory of reasoned action and extends the theory with country-of-origin construct. In line with this purpose, two models were created for German and Chinese COVID-19 vaccine, hypotheses were formed and tested.

Two separate models were formed to analyze the relationships between subjective norms, attitude towards COVID-19 vaccine, country of origin image, and vaccination intention. Furthermore, the mediating role of attitude in the relationship between country of origin and vaccination intention, and the moderating role of individual innovativeness in the relationship between country of origin and vaccination intention were analyzed. Results for Germany show that the most important factor related to getting the German vaccine is the attitude towards German COVID-19 vaccine $(\beta=0.888, \mathrm{p}<0.001)$. The finding underlines that to increase the intention to get the German COVID-19 vaccine, creating positive attitudes towards German COVID-19 vaccine should be prioritized. When people think that getting the vaccine is logical, their intention to get the German COVID-19 vaccine increases. The second important variable to explain intention to get German COVID-19 vaccine is Germany's country of origin image $(\beta=0.436, p<0.001)$. In addition, Germany's country of origin image is positively related to attitude towards German COVID-19 vaccine $(\beta=0.690, \mathrm{p}<0.001)$. It should be underlined that country of image is related to both attitudes toward German COVID-19 vaccine and intention to get German COVID-19 vaccine. On the other hand, attitude towards German COVID-19 vaccine mediates the relationship between Germany's country of origin and intention to get German COVID-19 vaccine. However, the research found that there is not a relationship between subjective norms and intention to get German COVID-19 vaccine. This finding indicates that significant others' opinion is not related to getting the German COVID-19 vaccine. Furthermore, individual innovativeness does not moderate the relationship between Germany's country of origin image and intention to get German COVID-19 vaccine.

Results for China demonstrate that the most important factor related to getting the Chinese COVID-19 vaccine are subjective norms $(\beta=0.750, \mathrm{p}<0.001)$. This finding indicates that if significant others expect individuals to get the vaccine, individuals are more inclined to get the Chinese COVID-19 vaccine. Therefore, it should be underlined that others opinions are essential to increase the likelihood of getting the Chinese COVID-19 vaccine. The second important variable to predict intention to get the Chinese COVID-19 vaccine is China's country of origin image $(\beta=0.265, p<0.001)$. Furthermore, there is a positive relationship between attitude towards Chinese COVID-19 vaccine and intention to get Chinese COVID-19 vaccine ( $\beta=0.198, p<0.001)$. Moreover, the study found a positive relationship between China's country of origin image and attitude towards Chinese COVID-19 vaccine $(\beta=0.461$, $\mathrm{p}<0.001)$. Attitude towards Chinese COVID-19 vaccine mediates the relationship between China's country of origin and intention to get Chinese COVID-19 vaccine while individual innovativeness does not moderate the relationship between China's country of origin and intention to get Chinese COVID-19 vaccine.

\section{CONCLUSION}

In conclusion, the study reveals that the most important variable related to getting the German COVID-19 vaccine is attitude towards the German COVID-19 vaccine whereas the most important variable related to get the Chinese COVID-19 vaccine is subjective norm. Country of origin is an essential variable for both countries and should be taken into account while researching medicine products.

Consumers take performance risk, financial risk, time risk, physical risk, social risk, and psychological risk while making buying decisions. Medicine and health industries are some of the most sensitive and significant industries from the point of risk factors. Therefore, decision-makers in the health industry should consider health risk and hesitation together with cost. From a marketing perspective, this study presented that country of origin image is a significant variable for the health industry and vaccination. The study highlights the importance of country of origin image, attitude, and subjective norms variables for the health industry.

Ethics Committee Approval: The study was approved by the Social and Humanities Research Ethics Committee of Y1ldız Technical University (2021/01).

Conflict of Interest: None declared by the authors.

Financial Disclosure: None declared by the authors.

Acknowledgements: None declared by the authors.

Author Contributions: Idea/Concept: KA, EÖÇ, ŞGK; Design: KA, EÖÇ, ŞGK; Data Collection/Processing: KA, EÖÇ, ŞGK; Analysis/Interpretation: KA, EÖÇ, ŞGK; Literature Review: KA, EÖÇ, ŞGK; Drafting/Writing: KA, EÖÇ, ŞGK; Critical Review: KA, EÖÇ, ŞGK.

\section{REFERENCES}

1. Kwok KO, Li KK, Wei WI, Tang A, Wong SYS, Lee SS. Editor's Choice: Influenza vaccine uptake, COVID19 vaccination intention and vaccine hesitancy among nurses: A survey. Int J Nurs Stud. 2021;114:103854

2. Palm R, Bolsen T, Kingsland JT. The effect of frames on COVID-19 vaccine hesitancy. MedRxiv. 2021. doi: 10.1101/2021.01.04.21249241

3. Salali GD, Uysal MS. COVID-19 vaccine hesitancy is associated with beliefs on the origin of the novel coronavirus in the UK and Turkey. Psychol Med. 2020; [Epub ahead of print]. doi: 10.1017/S0033291720004067.

4. Motta M. Can a COVID-19 vaccine live up to Americans' expectations? A conjoint analysis of how vaccine characteristics influence vaccination intentions. Social Science \& Medicine. 2021;272:113642.

5. Sallam M. COVID-19 vaccine hesitancy worldwide: a concise systematic review of vaccine acceptance rates. Vaccines (Basel). 2021;9(2):160. 
6. Fishbein M. A behavior theory approach to the relations between beliefs about an object and the attitude toward the object. In: Fishbein M, editor. Readings in attitude theory and measurement. New York: John Wiley \& Sons; 1967. p.389-400.

7. Madden TJ, Ellen PS, Ajzen I. A comparison of the theory of planned behavior and the theory of reasoned action. Pers Soc Psychol Bull.1992;18(1):3-9.

8. Atılgan KÖ. Gerekçeli eylem teorisi In: Yağcı Mİ, Çabuk S, editors. Pazarlama teorileri. İstanbul: MediaCat; 2014. p. 297-310,

9. Hale J, Householder BJ, Greene KL. The theory of reasoned action. In: Dillard JP, Pfau M, editors. The persuasion handbook: Developments in theory and practice. London, UK: Sage Publications; 2002. p.259-86.

10. Kotler P, Gertner D. Country as brand product and beyond: A place marketing and brand management perspective. J Brand Manag. 2002;9(4):249-61.

11. Aydin K, Say AT, Ustaahmetoglu E, Yamamoto GT. Attitudes of students toward country-of-origin and auto brand images. Serb J Manag. 2007;2(2):205-16.

12. Carneiro J, Faria F. Quest for purposefully designed conceptualization of the country-of-origin image construct. J Bus Res. 2016;69(10):4411-20.

13. Lu IR, Kwan E, Heslop LA, Thomas DR, Cedzynski $M$. The ivory tower and the street: How researchers defined country image over four decades and what consumers think it means. J Bus Res. 2019;105:80-97.

14. Sentürk T. Ülke imajı araştırmalarında ölçek seçimi ve kullanımı. Selçuk Üniversitesi Sosyal Bilimler Meslek Yüksekokulu Dergisi. 2018;21(1):78-91.

15. Nagashima A. A comparison of Japanese and US attitudes toward foreign products. J Mark. 1970;34(1):68-74.

16. Kaynak E, Cavusgil ST. Consumer attitudes towards products of foreign origin: do they vary across product classes? Int J Advert. 1983;2(2):147-57.

17. Nguyen AHM, Alcantara LL. The interplay between country-of-origin image and perceived brand localness: An examination of local consumers' response to brand acquisitions II emerging market firms. J Mark Commun. 2020; [Epub ahead of print]. doi: 10.1080/13527266.2020.1840422

18. Demirel EÜ. Ülke imajının satın alma istekliliği üzerindeki etkisinde tüketici yakınlığı ürün ülke imajı ve ürün yargılarının aracılık rolü. İşletme Araştırmaları Dergisi. 2020;12(2):1225-38.

19. Hien N, Phuong N, Tran T, Thang L. The effect of country-of-origin image on purchase intention: The mediating role of brand image and brand evaluation. Manag Sci Lett. 2020;10(6):1205-12.

20. Lee H, Chae MS, Lew YK. The application of categorization and stereotype content theories to country of origin image: Vietnamese perceptions towards Korean wave brands. Asia Pac Bus Rev. 2020;26(3):336-61.

21. Lin LY, Chen CS. The influence of the country-oforigin image product knowledge and product involvement on consumer purchase decisions: an empirical study of insurance and catering services in Taiwan. J Consum Mark. 2006;23(5):248-65.

22. Wang X, Yang Z. Does country-of-origin matter in the relationship between brand personality and purchase intention in emerging economies? Evidence from China's auto industry. Int Mark Rev. 2008;25(4):458-74.

23. Crouch RC, Lu VN, Pourazad N, Ke C. Investigating country image influences after a product-harm crisis. Eur J Mark. 2020;55(3):894-924.

24. Sanyal SN, Datta SK. The effect of country of origin on brand equity: an empirical study on generic drugs. J Prod Brand Manag. 2011;20(2):130-40.

25. Smaoui F, Kilani FA, Touzani M. Country-of-origin versus brand: consumers' dilemma when choosing between generic and branded drugs in emerging countries. J Prod Brand Manag. 2016;25(2):148-59.

26. Habash R, Al-Dmour H. Factors influencing the intention to buy over-the-counter medicines: empirical study. Int J Pharm Healthc Mark. 2020;14(2):305-23.

27. Agarwal R, Prasad J. A conceptual and operational definition of personal innovativeness in the domain of information technology. Inf Syst Res. 1998;9(2):204-15.

28. Rogers EM, Shoemaker FF. Communication of innovations; a cross-cultural approach. New York: Free Press; 1971.

29. Goldsmith RE. Using the domain specific innovativeness scale to identify innovative internet consumers. Internet Res. 2001;11(2):149-58.

30. Lee Y, Colarelli O'Connor G. The impact of communication strategy on launching new products: The moderating role of product innovativeness. J Prod Innov Manag. 2003;20(1):4-21.

31. Huang TL, Liao S. A model of acceptance of augmented-reality interactive technology: the moderating role of cognitive innovativeness. Electron Commer Res. 2015;15(2):269-95.

32. Sadik-Rozsnyai O, Bertrandias L. New technological attributes and willingness to pay: the role of social innovativeness. European Journal of Marketing. 2019;53(6):1099-124.

33. Flynn LR, Goldsmith RE. A validation of the Goldsmith and Hofacker innovativeness scale. Educ Psychol Meas. 1993;53(4):1105-16.

34. Nysveen H, Pedersen PE, Thorbjørnsen H. Intentions to use mobile services: Antecedents and cross-service comparisons. J Acad Mark Sci. 2005;33(3):330-346.

35. Hamari J, Sjöklint M, Ukkonen A. The sharing economy: Why people participate in collaborative consumption. J Assoc Inf Sci Technol. 2016;67(9):2047-59.

36. Sherman SM, Smith LE, Sim J, Amlôt R, Cutts M, Dasch H, et al. COVID-19 vaccination intention in the UK: results from the COVID-19 vaccination acceptability study (CoVAccS), a nationally representative cross-sectional survey. Hum Vaccin Immunother. 2020; [Epub ahead of print]. doi: 10.1080/21645515.2020.1846397.

37. Sharma S. Applied multivariate techniques. New York, NY: Wiley; 1996.

38. Hair JF, Black WC, Babin BJ, Anderson RE. Multivariate data analysis. 7th ed. New Jersey: Pearson education; 2010.

39. Hair JF, Black WC, Babin BJ, Anderson RE, Tatham RL. Multivariate data analysis. 6th ed. New Jersey: Pearson education; 2006.

40. Hair JF, Black WC, Babin BJ, Anderson RE. Multivariate data analysis. Pearson new international edition. Harlow: Pearson Education Limited; 2014. 
41. Fornell C, Larcker DF. Evaluating structural equation models with unobservable variables and measurement error. J Mark Res. 1981;18(1)39-50.

42. Henseler J, Ringle CCOI, Sarstedt M. A new criterion for assessing discriminant validity in variance-based structural equation modeling. J Acad Mark Sci. 2015;43(1):115-35.
43. Tabachnick B, Fidell L. Using multivariate statistics. London: Pearson; 2012.

44. Yaşlığlu MM. Sosyal bilimlerde faktör analizi ve geçerlilik: Keşfedici ve doğrulayıcı faktör analizlerinin kullanılması. İstanbul Üniversitesi İşletme Fakültesi Dergisi. 2017;46(Özel Say1):74-85. 